Acta vet. scand. $1978,19,179-183$.

From The State Veterinary Serum Laboratory, Copenhagen, Denmark.

\title{
UTILISATION OF GLUCOSE BY MYCOPLASMA SUIPNEUMONIAE AND MYCOPLASMA FLOCCULARE
}

\author{
By \\ P. Thode Jensen, C. Wolstrup and N. F. Friis
}

THODE JENSEN, P., C. WOLSTRUP and N. F. FRIIS: Utilisation of glucose by Mycoplasma suipneumoniae and Mycoplasma flocculare. Acta vet. scand. 1978, 19, 179-183. - The utilisation of glucose by Mycoplasma suipneumoniae and Mycoplasma flocculare was examined by chemical determination of glucose disappearance during growth, and by examination for hexokinase activity in cell preparations. Both species degraded glucose during growth and possessed hexokinase activity as evidence of the presence of a glycolytic pathway. The glucose utilisation capacity was found to be greater for $M$. flocculare than for M. suipneumoniae.

Mycoplasma suipneumoniae; Mycoplasma flocculare; glucose utilisation; hexokinase activity.

Doubt has arisen about the ability of the 2 porcine species of mycoplasma, M. suipneumoniae (M. suip.) and M. flocculare (M. floc.) to metabolise glucose. 'This doubt emanates mainly from difficulties that have been experienced in performing certain standard tests, and which are probably associated with modifications of the growth medium necessary for the performance of the tests, but unfavorable to the growth of the organisms (Friis 1974).

It was found pertinent to investigate more closely the glucosemetabolising capability of $M$. suip. and M. floc.. This was done partly by direct estimation of the utilisation of glucose during growth, partly by examination of a hexokinase activity, which, as recommended by Edward \& Razin (1974), can be used as indicator of the presence of a glycolytic pathway in the mycoplasmas. 


\begin{abstract}
MATERIAL AND METHODS
Strains of mycoplasma

Utilisation of glucose during growth was estimated chemically for the type strains of M. suip. and M. floc., i.e. strain "J", NCTC 10121, and strain Ms 42, NCTC 10143, resp., and for 4 Danish strains of each species, which had been cloned twice on solid medium. Examination for hexokinase activity was made on the type strains only.
\end{abstract}

\title{
Metabolism of glucose
}

The mycoplasmas were cultivated in a standard medium (Friis 1975) enriched with $0.2 \mathrm{mg}$ glucose per $\mathrm{ml}$ and adjusted to $\mathrm{pH}$ 7.6. They were propagated several times in tubes, and finally $1 \mathrm{ml}$ culture was added to $49 \mathrm{ml}$ broth in a $500-\mathrm{ml}$ glass bottle. The cultures were placed in a rolling drum and incubated at $37^{\circ} \mathrm{C}$ for 5 days in the case of M. suip. and for 6 days in the case of M. floc. On titration in broth the $1 \mathrm{ml}$ inoculum was found to contain $5 \times 10^{7}$ or $5 \times 10^{8}$ color changing units per $\mathrm{ml}$. Before and after growth the glucose concentrations in the broth cultures were determined by the glucose oxidase method $(\mathrm{Kabi} \circledast)$, and the final $\mathrm{pH}$ measured.

Hexokinase assay (Cirillo \& Razin (1973) with some modifications)

Concentrated mycoplasma suspensions were obtained from a 2-1 culture of $M$. suip. and a 1-1 culture of $M$. floc. by centrifugation at $20,000 \times \mathrm{g}$ late in the logarithmic growth phase. The sediment was washed 3 times with PBS, suspended in $3.5 \mathrm{ml}$ distilled water, and frozen-and-thawed 5 times. The cell-protein content in the preparations was measured by the method of Lowry et al. (1951) using bovine serum albumin as a standard.

The hexokinase activity in $0.6 \mathrm{ml}$ mycoplasma preparation was tested in $1 \mathrm{ml}$ of a reaction mixture containing $8 \mu$ moles of $\mathrm{MgCl}_{2}$, $16 \mu$ moles of NaF, $4 \mu$ moles ATP (Sigma No. A-3127) and $80 \mu$ moles $\mathrm{K}_{2} \mathrm{HPO}_{4}, \mathrm{pH} 8$. After pre-heating to $37^{\circ} \mathrm{C} 1 \mu$ mole ${ }^{14} \mathrm{C}$-glucose $(0.05 \mu$ $\mathrm{Ci} / \mu$ mole, The Radiochemical Centre, Amersham, England) was added. The reaction at $37^{\circ} \mathrm{C}$ was terminated after $60 \mathrm{~min}$. by cooling in an ice-bath and by adding $5 \mathrm{ml}$ ice-cold distilled water. The preparations were centrifuged at $12,000 \times \mathrm{g}$ for $10 \mathrm{~min}$. at $4^{\circ} \mathrm{C}$. The supernatants were placed on ion-exchange columns (Pasteur pipettes with $3.5 \mathrm{ml}$ Dowex $1 \times 2\left(50-100\right.$ mesh) in the $\mathrm{Cl}^{-}$form, Serva No. 41011) and the unphosphorylated glucose washed out of the columns with $20 \mathrm{ml}$ distilled water and collected in fractions. The glucose phosphate was eluted with $6 \mathrm{ml} 1.0 \mathrm{M}-\mathrm{LiCl}$ and the eluate collected for scintillation counting. The tests were made in duplicate, and the procedure was repeated at $0^{\circ} \mathrm{C}$. One thirtieth of the $\mathrm{LiCl}$ eluate was mixed with $2 \mathrm{ml}$ Instagel (Packard Instrument Co.) and counted for 20 min. in a Beckman LS-100 C liquid scintillation spectrometer. All countings were made in triplicate. The ${ }^{14} \mathrm{C}$-glucose solution was counted in the same way.

The results are expressed in counts per min. (c.p.m.) - the same 
counting efficiency for all samples - and calculated as nmole glucose phosphorylated per mg cell protein per min.

The last fractions from the washings with distilled water were counted to control the washing efficiency.

\section{RESULTS}

As appears from Table 1 , all the strains of $M$. suip. and $M$. floc. caused a reduction in the concentration of glucose during the growth. The reduction, as well as the accompanying fall of the $\mathrm{pH}$, was more pronounced in the cultures of $\mathrm{M}$. floc. than in those of M. suip.

The results obtained by examination for hexokinase activity are given in Table 2. As there was no real difference between replicates the individual countings were used to estimate the mean and the variance for each group. The protein content of the mycoplasma preparations was $17.8 \mathrm{mg} / \mathrm{ml}$ (M. suip.) and $8.0 \mathrm{mg} / \mathrm{ml}$ (M. floc.). For M. suip., Student's t-test showed a significant difference between mean c.p.m. at $37^{\circ} \mathrm{C}$ and mean c.p.m. at $0^{\circ} \mathrm{C}(\mathrm{P}<0.001)$ which indicates hexokinase activity.

T a b l e 1. Utilisation of glucose by strains of $M$. suipneumoniae and M. flocculare in broth cultures.

\begin{tabular}{llccc}
\hline Strains of mycoplasma & $\begin{array}{l}\text { Concentration of glucose, } \mathrm{mg} / \mathbf{1 0 0} \mathrm{ml} \\
\text { before } \\
\text { growth }\end{array}$ & $\begin{array}{c}\text { after } \\
\text { growth }\end{array}$ & $\begin{array}{c}\text { pH after } \\
\text { growth }\end{array}$ \\
\hline decrease & & \\
M. suip. & & & & \\
type strain ${ }^{\star \star}$ & $204^{\star \star}$ & 152 & 52 & 6.12 \\
Ms 1 & 206 & 185 & 21 & 6.52 \\
Ms 2 & 200 & 182 & 18 & 6.50 \\
Ms 5 & 204 & 175 & 29 & 6.43 \\
Ms 6 & 203 & 169 & 34 & 6.38 \\
M. floc. & & & & \\
type strain ${ }^{\star \star}$ & 199 & 99 & 100 & 5.69 \\
Ms 26 & 191 & 99 & 92 & 5.67 \\
Ms 30 & 197 & 92 & 105 & 5.60 \\
Ms 31 & 198 & 93 & 105 & 5.61 \\
Ms 46 & 199 & 120 & 79 & 5.91 \\
\hline
\end{tabular}

* Five days of incubation for strains of M. suip. and 6 days for strains of M. floc.

* * Examinations of strains of M. suip. and strains of M. floc. were carried out on different days.

* * * Strain "J", NCTC 10121 of M. suip., and strain Ms 42, NCTC 10143 of M. floc. 
T a ble 2. Hexokinase activity in preparations of $M$. suipneumoniae and M. flocculare.

\begin{tabular}{lcc}
\hline & M. suipneumoniae & M. flocculare \\
\hline $\begin{array}{l}\text { c.p.m. }\left(\mathrm{LiCl} \text { eluate, } 37^{\circ} \mathrm{C}\right) \\
\text { mean } \pm \mathrm{s}(\mathrm{n}=6)\end{array}$ & $78.7 \pm 0.81$ & $158.5 \pm 1.15$ \\
$\begin{array}{l}\text { c.p.m. }\left(\mathrm{LiCl} \text { eluate, } 0^{\circ} \mathrm{C}\right) \\
\text { mean } \pm \mathrm{s}(\mathrm{n}=6)\end{array}$ & $69.0 \pm 0.76$ & $76.5 \pm 0.80$ \\
$\begin{array}{l}\text { Hexokinase activity } \\
\text { (nmoles glucose phosphorylated }\end{array}$ & & \\
per mg cell protein per min.) & 0.007 & 0.142 \\
\hline
\end{tabular}

In the case of $M$. floc. no test for significance was applied, as the difference between the mean c.p.m. values at the 2 temperatures was obvious. Although the conditions of reaction were not optimised, the great difference between the results indicates a higher hexokinase activity in M. floc. than in M. suip.

\section{DISCUSSION}

Degradation of glucose by mycoplasmas is generally estimated by an indirect method, in which a lowered $\mathrm{pH}$ resulting from growth of the organisms in a glucose-containing liquid medium is taken to indicate a positive reaction (Aluotto et al. 1970). However, the method may lead to misinterpretation, and even the use of proper controls does not exclude difficulties and pitfalls (Subcommittee on the Taxonomy of Mycoplasmatales 1972). Edward \& Moore (1975) proposed a chemical estimation of glucose utilisation, and Edward \& Razin (1974) recommended determination of hexokinase activity as evidence of the presence of a glycolytic pathway.

In the present investigation the glucose utilisation by M. suip. and M. floc. was examined by the above-mentioned methods, and good agreement was found between the results. Although both mycoplasmas were able to utilise glucose, the fact that $M$. floc. showed a higher hexokinase activity and a greater glucose consumption than M. suip. would seem to suggest that the former has a greater capacity for utilisation of glucose than the latter.

\section{REFERENCES}

Aluotto, B. B., R. G. Wittler, C. O. Williams \& J. E. Faber: Standardized bacteriologic techniques for the characterization of Mycoplasma species. Int. J. system. Bact. 1970, 20, 35-58. 
Cirillo, V. P. \& S. Razin: Distribution of a phosphoenolpyruvatedependent sugar phosphotransferase system in mycoplasmas. J. Bact. 1973, 113, $212-217$.

Edward, D. G. \& W. B. Moore: A method for determining the utilization of glucose by mycoplasmas. J. med. Microbiol. 1975, 8, 451-454.

Edward, D. G. \& S. Razin: The determination of metabolism of glucose. WHO Communication 2, 1974.

Friis, N. F.: Mycoplasmas in Pigs with Special Regard to the Respiratory Tract. Thesis. DSR Forlag, Copenhagen 1974.

Friis, N. F.: Some recommendations concerning primary isolation of Mycoplasma suipneumoniae and Mycoplasma flocculare. Nord. Vet.-Med. 1975, 27, 337-339.

Lowry, O. H., N. J. Rosebrough, A. L. Farr \& R. J. Randall: Protein measurement with the Folin phenol reagent. J. biol. Chem. 1951, 193, 262-275.

Subcommittee on the Taxonomy of Mycoplasmatales: Proposal for minimal standards for descriptions of new species of the order Mycoplasmatales. Int. J. system. Bact. 1972, 22, 184-188.

\section{SAMMENDRAG}

Undersøgelse af Mycoplasma suipneumoniae's og Mycoplasma flocculare's evne til at forgære glukose.

Mycoplasma suipneumoniae's og Mycoplasma flocculare's evne til at forgære glukose blev unders $\varnothing$ gt ved kemisk bestemmelse af glukoseforbruget under vækst og ved unders $\varnothing$ gelse for hexokinaseaktivitet i cellepræparater. Det fandtes, at begge arter forgærede glukose under væksten, ligesom begge arter var $\mathrm{i}$ besiddelse af hexokinaseaktivitet som tegn på udøvelse af glykolytisk metabolisme. Der fandtes st $\varnothing$ rre glukoseforgæringsaktivitet for M. flocculare end for M. suipneumoniae.

(Received October 27, 1977).

Reprints may be requested from: T. Thode Jensen, The State Veterinary Serum Laboratory, Bülowsvej 27, DK-1870 Copenhagen V, Denmark. 